\title{
A Stability Mathematical Model of Nasopharyngeal Carcinoma on Cellular Level
}

\author{
Sugiyanto $^{1}$, Fajar Adi Kusumo ${ }^{2}$, Lina Aryati ${ }^{3}$, Mardiah Suci Hardianti ${ }^{4}$ \\ ${ }^{1}$ Doctoral Student of Mathematics Department; ${ }^{2,3}$ Mathematics Department; ${ }^{4}$ Faculty of Medicine, Universitas Gadjah Mada, \\ Bulaksumur, Caturtunggal, Kec. Depok, Kabupaten Sleman, Daerah Istimewa Yogyakarta 55281 Indonesia \\ ${ }^{1}$ Mathematics Department, Faculty of Science and Technology, UIN Sunan Kalijaga, \\ J1. Marsda Adisucipto No 1 Yogyakarta 55281, Indonesia. Tel. +62-274-540971, Fax. +62-274-519739
}

Author correspondency:

sugimath@yahoo.co.id ${ }^{1}$

\begin{abstract}
This paper discussed the stability of "Tumorigenesis Models" to link between EBV and carcinoma of the nasopharyngeal from normal cell to invasive carcinoma. The review on this case accomplished the previous theorem of equilibrium point on "Tumorigenesis Models".
\end{abstract}

Keywords: Nasopharyngeal Carcinoma; Equilibrium Point; Stability; Mathematical model.

PACS: 87.19.xj.

\section{INTRODUCTION}

Nasopharyngeal carcinoma (NPC) is a malignancy which is derived from epithelial or mucosa and kripta that coat the surface of nasopharynx. According to Munir (2006) in Indonesia nasopharyngeal carcinoma is the most excessively founded in the ear, nose, throat domain and the most patient are at age 40 or older. Soetjipto (1989) said that prevalence of nasopharyngeal carcinoma in Indonesia is 4,7/100.000 inhabitant per year. Whereas nasopharyngeal carcinoma cases in Sardjito Hospital in 2011 are comprised of 31 men and 11 women (Ratnawati, 2012).

In the previous paper we published a mathematical modeling of "Tumorigenesis Models" for EBV- assosiated nasopharyngeal carcinoma and analyzed the equilibrium point of the cell development from normal cell to invansive carcinoma (Lo et al., 2012). This paper will described the stability mathematical model from normal cell to invansive carcinoma.

\section{MATHEMATICAL MODELING}

As discussed in previous paper (Sugiyanto et al., 2016), with refer to process "Tumorigenesis Models" for EBVassosiated nasopharyngeal carcinoma (Lo et al., 2012), then we can construct the diagram as follows:

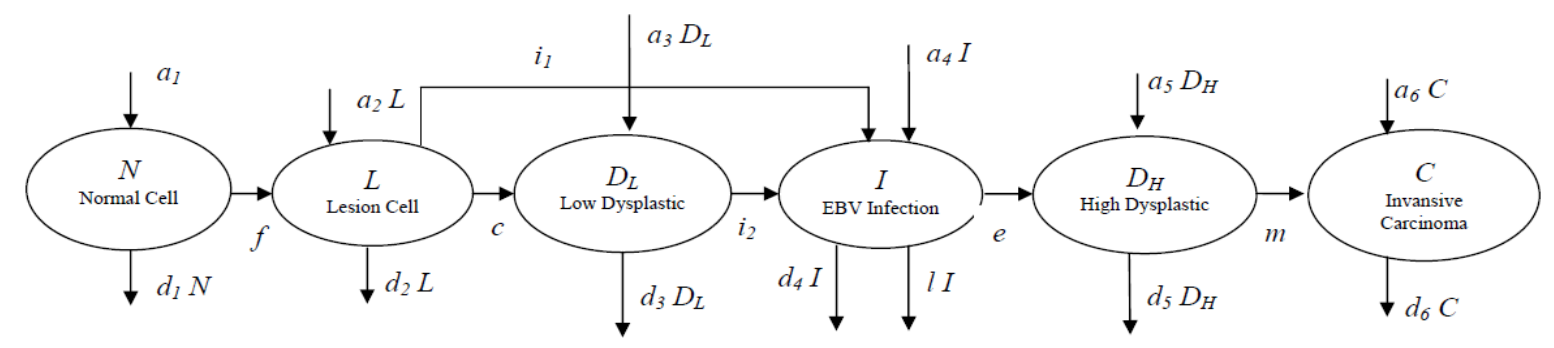

Figure 1. Diagram of nasopharyngeal carcinoma infection process.

From the diagram above we obtain system of differentional equations that describes "Tumorigenesis
Models” for EBV-assosiated nasopharyngeal carcinoma as follows (Lo et al., 2012). 


$$
\begin{aligned}
& \frac{d N}{d t}=a_{1}-b N-d_{1} N \\
& \frac{d L}{d t}=a_{2} L+b N-c L-i_{1} L-d_{2} L \\
& \frac{d D_{L}}{d t}=a_{3} D_{L}+c L-i_{2} D_{L}-d_{3} D_{L} \\
& \frac{d I}{d t}=a_{4} I+i_{2} D_{L}-e I-l I-d_{4} I \\
& \frac{d D_{H}}{d t}=a_{5} D_{H}+e I-m D_{H}-d_{5} D_{H} \\
& \frac{d C}{d t}=a_{6} C+m D_{H}-d_{6} C
\end{aligned}
$$

Where

$N(t)$ : The density of nasopharynx normal epithelium cell

$L(t) \quad$ : The density of lesions epithelium cell

$D_{L}(t)$ : The density of low grade dysplastic lesions cell

$I(t) \quad$ : The density of EBV latent infection cell

$D_{H}(t)$ : The density of high grade dysplastic lesions cell $C(t) \quad$ : The density of invansive carcinoma.

The equilibrium point of system differential equations (1) to (6) is,

$$
\begin{aligned}
& N^{*}=\frac{a_{1}}{b+d_{1}} \\
& L^{*}=\frac{b N^{*}}{\left(c+i_{1}+d_{2}-a_{2}\right)} \\
& D_{L}^{*}=\frac{c L^{*}}{\left(d_{3}+i_{2}-a_{3}\right)} \\
& I^{*}=\frac{i_{2} D^{*}}{\left(e+l+d_{4}-a_{4}\right)} \\
& D_{H}^{*}=\frac{e I^{*}}{\left(m+d_{5}-a_{5}\right)} \\
& C^{*}=\frac{m D_{H} *}{\left(d_{6}-a_{6}\right)}
\end{aligned}
$$

\section{Where}

$$
\begin{aligned}
& c+i_{1}+d_{2}-a_{2}>0 \\
& d_{3}+i_{2}-a_{3}>0 \\
& e+l+d_{4}-a_{4}>0 \\
& m+d_{5}-a_{5}>0 \\
& d_{6}-a_{6}>0
\end{aligned}
$$

\section{STABILITY EQUILIBRIUM POINT}

The Jacobian matrix of system differential equations (1) is,
$J\left(N, L, D_{L}, I, D_{H}, C\right)=J(E)$

where $E$ is the equilibrium condition.

The characteristic equation is,

$\left(-b-d_{1}-\lambda\right)\left(a_{2}-c-i_{i}-d_{2}-\lambda\right)$

$\left(a_{3}-i_{2}-d_{3}-\lambda\right)\left(a_{4}-e-l-d_{4}-\lambda\right)$

$\left(a_{5}-m-d_{5}-\lambda\right)\left(a_{6}-d_{6}-\lambda\right)=0$

After some calculations we get,

$\lambda_{1}=-\left(b+d_{1}\right)$.

$\lambda_{2}=a_{2}-c-i_{i}-d_{2}$.

$\lambda_{3}=a_{3}-i_{2}-d_{3}$.

$\lambda_{4}=a_{4}-e-l-d_{4}$.

$\lambda_{6}=a_{5}-m-d_{5}$.

$\lambda_{7}=a_{6}-d_{6}$.

\section{Lemma 1.}

The equilibrium point $E\left(N^{*}, L^{*}, D_{L}^{*}, I^{*}, D_{H}{ }^{*}, C^{*}\right)$ is asymptotic stable if, $a_{2}<c+i_{i}+d_{2}, a_{3}<i_{2}+d_{3}$, $a_{4}<e+l+d_{4}, a_{5}<m+d_{5}$, and $a_{6}<d_{6}$.

In a medical point of view, in order to avoid the cancer cells then the abnormal cell should be dead quickly until the amount of proliferation cells smaller then apoptosis, so a stability will be formed, which mean that the cancer do not develop. Killing abnormal cells need a highly immunogenic (Janeway et al., 2001). In the stage of nasopharynx carcinoma, killing cancer cells will be more difficult, because cancer cels have characteristic of resisting cell death (Hanahan \& Weinberg, 2011).

\section{SIMULATION}

The selected parameters are given in tabular form below.

Case I : Not infected with EBV.

Case II : EBV infected but do not develop nasopharyngeal carcinoma.

Case III : Infected EBV and nasopharyngeal carcinoma develops.

\section{For case I:}

In the first case of this sub-population: cells infected, high dysplastic lesion cells, and invansive carcinoma cells is zero.

$$
I(t)=0 \quad D_{H}(t)=0 \quad C(t)=0
$$

System differential equations (1) to (6) became system differential equations (1) to (3). 
Table 1. The values parameter for first case, not infected by EBV.

\begin{tabular}{cccc}
\hline No. & Parameter & Value & Unit \\
\hline 1. & $a_{1}$ & 100 & $1 /$ day \\
2. & $a_{2}$ & 1 & $1 /$ day \\
3. & $a_{3}$ & 1 & $1 /$ day \\
4. & $d_{1}$ & 0.08 & $1 /$ day \\
5. & $d_{2}$ & 20 & $1 /$ day \\
6. & $d_{3}$ & 2 & $1 /$ day \\
7. & $b$ & 1 & $1 /$ day \\
8. & $c$ & 0.5 & $1 /$ day \\
9. & $i_{1}$ & 0.1 & $1 /$ day \\
10. & $i_{2}$ & 0.5 & $1 /$ day \\
\hline
\end{tabular}

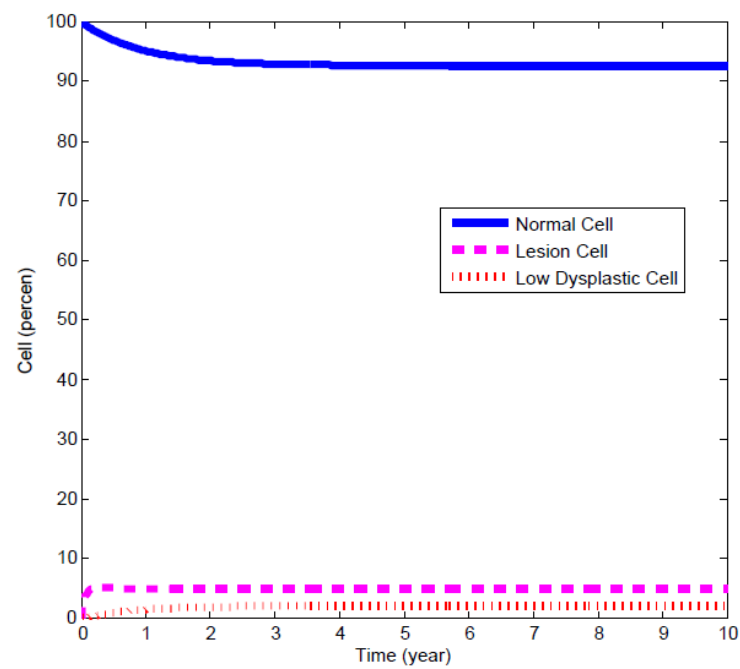

Figure 2. The process of cell development in the case which is not infected with EBV.

In Figure 2, EBV is not detected in the body. In the first case, the normal cell decreased, while there was an increase lesion cell. Then the cell becomes low dysplastic lesion cell because p16 is inactive. Because there is no detection of EBV then the high dysplastic cells did not happen and does not became to invasive carcinoma. This is consistent with description from Figure 2.

\section{For this case II:}

In the second case of this sub-population: high dysplastic lesion cells and invansive carcinoma cells is zero.

$$
D_{H}(t)=0 \quad C(t)=0
$$

System differential equations (1) to (6) became system differential equations (1) to (4).
Table 2. The values parameter for case infected by EBV, but did not develop nasopharyngeal carcinoma.

\begin{tabular}{cccc}
\hline No. & Parameter & Value & Unit \\
\hline 1. & $a_{1}$ & 100 & $1 /$ day \\
2. & $a_{2}$ & 1 & $1 /$ day \\
3. & $a_{3}$ & 1 & $1 /$ day \\
4. & $a_{4}$ & 1 & $1 /$ day \\
5. & $d_{1}$ & 0.2 & $1 /$ day \\
6. & $d_{2}$ & 8 & $1 /$ day \\
7. & $d_{3}$ & 2 & $1 /$ day \\
8. & $d_{4}$ & 2 & $1 /$ day \\
9. & $b$ & 1 & $1 /$ day \\
10. & $c$ & 4 & $1 /$ day \\
11. & $i_{1}$ & 0.1 & $1 /$ day \\
12. & $i_{2}$ & 2 & $1 /$ day \\
13. & $e$ & 0.1 & $1 /$ day \\
14. & $l$ & 1 & $1 /$ day \\
\hline
\end{tabular}

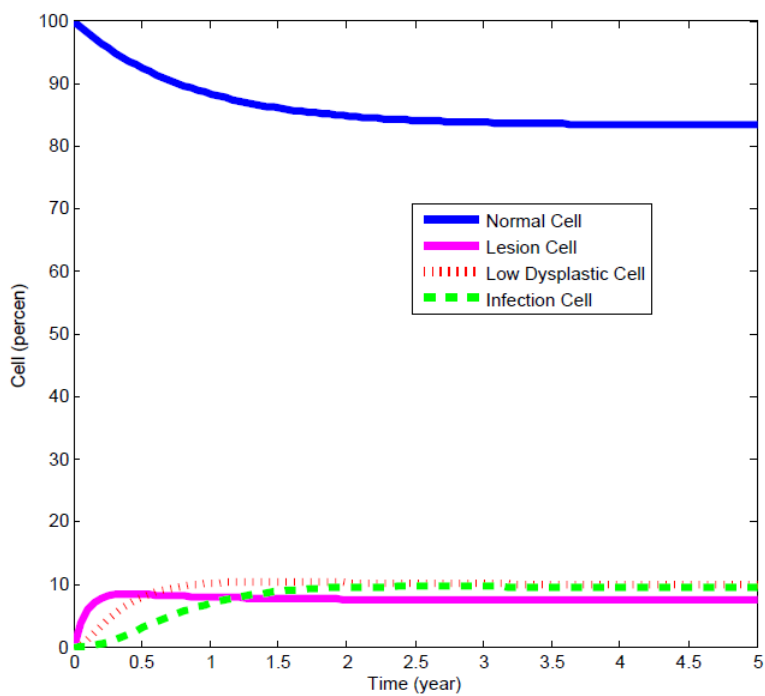

Figure 3. The process of case development of EBV-infected cells, but did not develop nasopharyngel carcinoma.

In Figure 3, EBV is detected in the body. In the second case, the normal cells decrease very rapidly in the early years and higher lesions cells which is very fast. When p16 is inactive, the lesion cells becomes low dysplastic cells. Presence of EBV lytic cause abnormal cells, low dysplastic cells, can easily be infected by EBV lytic and makes infected cells. The EBV lytic there is an increase, although not significant.

\section{For this case III:}

System differential equations same with system differential equations (1) to (6). 
Table 3. The values parameter for case infected by EBV and developing nasopharyngeal carcinoma.

\begin{tabular}{|c|c|c|c|}
\hline No. & Parameter & Value & Unit \\
\hline 1. & $a_{1}$ & 100 & 1/day \\
\hline 2. & $a_{2}$ & 2 & 1/day \\
\hline 3. & $a_{3}$ & 1 & $1 /$ day \\
\hline 4. & $a_{4}$ & 1 & $1 /$ day \\
\hline 5. & $a_{5}$ & 2 & $1 /$ day \\
\hline 6. & $a_{6}$ & 2 & $1 /$ day \\
\hline 7. & $a_{7}$ & 2 & $1 /$ day \\
\hline 8. & $d_{1}$ & 1 & $1 /$ day \\
\hline 9. & $d_{2}$ & 2 & $1 /$ day \\
\hline 10. & $d_{3}$ & 2 & 1/day \\
\hline 11. & $d_{4}$ & 2 & $1 /$ day \\
\hline 12. & $d_{5}$ & 3 & 1/day \\
\hline 13. & $d_{6}$ & 3 & $1 /$ day \\
\hline 14. & $d_{7}$ & 1 & 1/day \\
\hline 15. & $\alpha$ & 5 & 1/day \\
\hline 16. & $\beta$ & 1 & 1/day \\
\hline 17. & $\gamma$ & 1 & 1/day \\
\hline 18. & $\theta$ & 5 & $1 /$ day \\
\hline 19. & $\delta$ & 2 & $1 /$ day \\
\hline 20. & $\varepsilon$ & 1 & 1/day \\
\hline 21. & $v$ & 2 & $1 /$ day \\
\hline 22. & $\lambda$ & 1 & 1/day \\
\hline
\end{tabular}

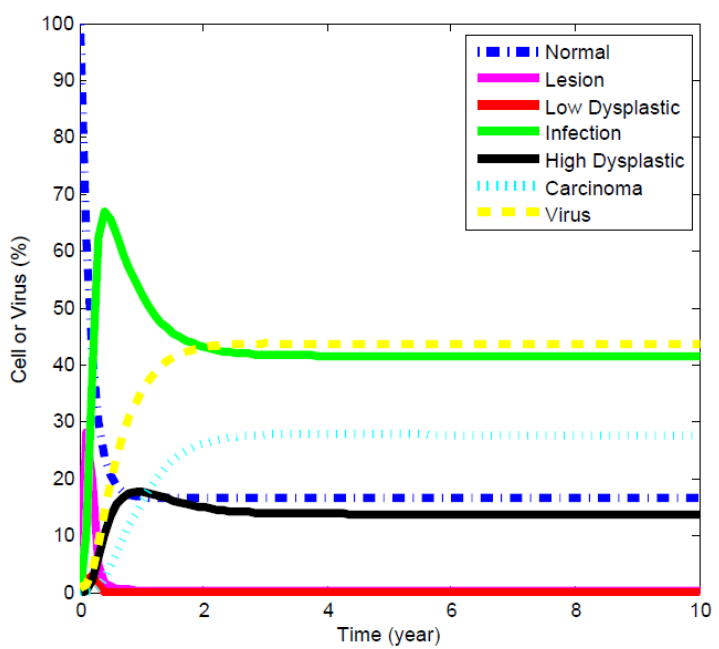

Figure 4. The process of development case of EBV-Infected and developing nasopharyngeal carcinoma.

In Figure 4, EBV is detected in the body. In the third case, because low immune system, lytic viruses evolve very rapidly. Thus making normal cell down very quickly, otherwise latent EBV-infected cells increased. This coincided with increase high dysplastic cells. The high growth fueled high dysplastic cells growth invasive carcinoma very quickly. These cases need special attention. We need for follow-up studies, so there is prevention in anticipation of invasive carcinoma. It should be a particular concern because it studied the beginning of nasopharyngeal carcinoma.

\section{CONCLUSION}

This paper have completed the equilibrium point system in (1). For the asymptotic stability on equilibrium point will be fulfilled if $a_{2}<c+i_{i}+d_{2}, a_{3}<i_{2}+d_{3}$, $a_{4}<e+l+d_{4}, a_{5}<m+d_{5}$, and $a_{6}<d_{6}$. It mean that to aim the stability it must fulfilled that the proliferation of lesion cells, low dyplastic cells, invection cells, hight dyplastic cells, and invansive carcinoma cells are smaller than the rate cell that go in the next direction compartment and died cells.

\section{ACKNOWLEDGMENTS}

Thank to Mr. M. Wakhid Musthofa, Mr. Ario Wiraya, Miss. Dewajani Purnomosari, Miss. Dewi Kartikawati Paramita, Miss. Jajah Fachiroh, Mr. Muhammad Ghufron over discussion and all their support.

\section{REFERENCES}

Hanahan D., and Weinberg R. A., 2011, Hallmarks of Cancer: The Next Generation, Cell 144, March 4, 2011, Elsevier Inc.

Janeway C. A Jr., Travers P., Walport M., et al.Immunobiology: The Imune System in Health and Disease. $5^{\text {th }}$ edition, NNew York: Garland Science: 2001Using the immune response to attack tumors. Available from: https://www.ncbi.nlm.nih.gov/books/NBK27104/

Lo, K.W., Chung, G.T., and To K.F., 2012. Deciphering the Molecular Genetic Basis of NPC Through Molecular, Cytogenetic, And Epigenetic Approaches, Seminars in Cancer Biology, 22 (2): 79 - 86.

Munir D., 2006. Beberapa Aspek Karsinoma Nasofaring pada Suku Batak di Medan dan Sekitarnya, The Journal of Medicine School University of Sumatera Utara, 39 (3): 223226.

Ratnawati H., 2012. Major Histocompability Complex Class-I Related Chain A (MICA) sebagai Kandidat Immunological Tumor Marker pada Penderita Karsinoma nasofaring, Dissertation: Doctoral Programs, Medicine and Health, Faculty of Gadjah Mada University, Yogyakarta.

Soetjipto, D, 1989. Karsinoma Nasofaring. Dalam: Tumor Telinga, Hidung dan Tenggorokan. Diagnosis dan penatalaksanaan, Balai Penerbit FK UI Jakarta, p. 71-84.

Sugiyanto, Fajar A. K., Lina A., Mardiah S. H., 2013, Mathematical Modeling of Nasopharynx Carcinoma on Cell Level, AIP Proceeding, http://scitation.aip.org/content/aip/proceeding/aipcp/10.1063/1 .4866540 ; jsessionid=2gqg1j7afdq12.x-aip-live- 02 . 